\title{
The Way into Transcendental Philosophy from the Argument in Suhrawardi's Philosophy of Illumination
}

https://doi.org/10.1515/opth-2019-0022

Received May 20, 2019; accepted June 14, 2019

\begin{abstract}
This paper presents a phenomenological analysis of the argument in The First Discourse of Part 2 of Suhrawardī's Philosophy of Illumination. Specifically, this argument is considered with regard to temporal extension of its logos, i.e., the succession of logical steps. Contrary to traditional views of Suhrawardi as a Neoplatonizing proponent of the primacy of essence over existence, the steps of his argument convey a much more nuanced picture in which light emerges as the main metaphysical principle. First, Suhrawardi explicates full evidentiality in visible light (which is the most patent, 'azhar, from the Arabic root $z$-h- $\mathrm{r}=$ 'to appear, be [made] manifest'): this light gives us the world as "this-there"; and second, as self-evidentiality (zuhūru-hu, 'being obvious to itself by itself') in the first-person consciousness of the knower. Suhrawardi accesses these modes by reduction(s) which liberate the transcendental character of light. The correlation in the evidential mode of light between the knower and the objects serves as a ground for the claims of transcendental unity of the self and the world, and as a condition of possibility for knowledge. A juxtaposition of this approach with phenomenological philosophy suggests that in Suhrawardi's analysis, the evidentiality of visual light plays a role of a new universal a priori. I show that under the phenomenological reduction, this a priori participates in constitution of ontological validities; and within the transcendental empiricism of the physics of light, this a priori underlies the construction of causality. Thereby, the Philosophy of Illumination suggests a new horizon of entry into transcendental phenomenological philosophy. The paper also contains a justification of a phenomenological reading of Suhrawardi's work, including explanation of the historical reduction.
\end{abstract}

Keywords: transcendental phenomenology, historical reduction, Husserl, Suhrawardi, Philosophy of Illumination, self-evidence, consciousness, light, unity

In this paper, ${ }^{1}$ I show that The Philosophy of Illumination (hereafter PI; Ḥikmat al-Ishrāq) ${ }^{2}$ of Shihāb al-Dīn Suhrawardī (1154-1191 C.E.; northwestern Iran and Anatolia) offers an interesting and possibly original way of entry into transcendental philosophy. By "transcendental philosophy," I mean not a general manner of philosophical or spiritual transcendental thinking, but specifically philosophy in and after Kant's transcendental turn and Husserl's transcendental phenomenology, all of which focus on the possibility of the self's knowledge of the world. ${ }^{3}$ To the latter problematic, Suhrawardi contributes his thesis of transcendental unity in the evidentiality of light.

1 I am grateful to James Hart and to both anonymous reviewers for their valuable reflections on this paper, and to Martin Schwartz for help with Arabic.

2 In citations, PI 1 and PI 2 refer respectively to Part 1 and Part 2 of PI. Numbers of sections are italicized; page numbers are shown in roman type.

3 For different strands of thinking about transcendence, including mysticism and Emersonian transcendentalism, see LaRocca, Bloomsbury Anthology. For Kant’s transcendental turn in philosophy, see Hartmann, “On Taking.”

\footnotetext{
*Corresponding author: Olga Louchakova-Schwartz, Graduate Theological Union and U.C. Davis, Berkeley, United States of America; E-mail: olouchakova@gmail.com
} 
Husserl introduces transcendental phenomenology with the following question: ${ }^{4}$ How does the world come to be a knowable a priori? Both common sense and objective/rational scientific thinking follow the unquestioned assumption of the existence of the world. According to phenomenology, this surrounding world, which is presupposed as existing, appears not just in perception but via meaning. ${ }^{5}$ This brings up a second question: How can consciousness develop meaning-configurations of an intuitively given surrounding world? The phenomenological approach maintains that the world is given in presentations (phenomena) and not in representations, which means both that the object is identical with its presentation in consciousness and that the reality of objects is completely correlated with how they appear to the knower. The objects are the objects we see. However, what one sees is subject to constitution by consciousness: the spatial objects of the world are given in multiple adumbrations, i.e., as "snapshots" of different sides of things; they appear as unified due to meaning-bestowing syntheses by the ego. From the aprioristic horizon of the world, the ego derives and posits the ontic validities of these unities in correlation with their existences in the world horizon. Overall, consciousness penetrates its own constitutive processes towards the objects themselves: one writes in a café, at the table, and not amidst adumbrations which are undergoing synthesis.

The "universal a priori of correlation" suggests some kind of underlying unity between the knowing subject and the world. Within phenomenology, different kinds of unity were implied: by the hermeneutics of intersubjectivity (Husserl), as the ontological monistic unity of being (Heidegger), by invisible ethical bonds between the self and others (Levinas), ${ }^{7}$ as the metaphysical unity of essence and manifestation (Henry), or, in realistic phenomenology (Seifert), in the mediated intimacy of knowledge, i.e., eidetic intuition of pure perfections. ${ }^{8}$ On this spectrum, Suhrawardī can be viewed as an early representative of phenomenological realism, who analyzes presentations and views consciousness under reduction (jarrada) ${ }^{9}$ but at the same time maintains the ideas of inclusion of subjectivity within the world and of the subject's unity with the world, ${ }^{10}$ notably while the latter is perceived as “external”. I will attempt to show Suhrawardī's position in PI by means of static phenomenological analysis which I conduct within the limits afforded by historical reduction, without going into detail regarding Suhrawardì's relationships with the Islamic philosophical tradition or Western interpretations of the latter. The reason for me to choose such an approach is a dissatisfaction with merely rationalistic readings of Suhrawardī. In light of such rationalism, even Husserl's transcendental idealism, which is not idealism per se but a transcendental philosophy grounded in the analysis of evidence, is often mistaken not only for idealism but even for the radical Platonic-Thomistic version of the latter. ${ }^{11}$ A similar misreading happens to Suhrawardī's philosophy of direct intuition. ${ }^{12}$ The goal of my paper does not consist in refuting such errors, even though the reader may find such criticism implicit. Essentially, I want to show how Suhrawardi explicates the ontological ground of transcendental unity in the context of supposition that his understanding of light can contribute to a phenomenological understanding of Selbstlichtkeit and of transcendental unity.

As noted by Russell, ${ }^{13}$ philosophy does not create a substantial body of definitive knowledge: as soon as philosophy discovers something new, the new propagates into a science. Accordingly, the value of philosophy is in philosophical thinking per se and, as in Husserl, ${ }^{14}$ in refinement of such thinking over the course of time in the life of the individual philosopher as well as in history. In the "rearview mirror" of scientific rationalism, $P I$ is objectified with regard to its "deliverables”, i.e., with regard to its fixed set of concepts and principles, original or borrowed, and not with regard to the manner of its lived reflection that brought out this unique philosophical intentional world. In the former scenario, one looks at the doctrinal issues, such as (e.g.) a primacy of essence versus existence or the emanationist account. In the latter scenario, one looks at intentionalities in the structure of the argument. Suhrawardī was quite familiar with different strands of Greek philosophy and various forms

\footnotetext{
4 Husserl, Crisis, 104.

5 Husserl, Logical Investigations, 83: "The appearing of the things does not itself appear to us, we live through it”.

6 Ibid., 159.

7 Bergo, "Emmanuel Levinas."

8 For interpretations of unity of the subject and the world, see Husserl, Crisis, 182-183; in Heidegger, see Wheeler, "Martin Heidegger”; in Henry, see Henry, Essence, sect. II; in realistic phenomenology, see Seifert, Discours, 32-35.

9 For the analysis of reduction in PI, see Louchakova-Schwartz, "Phenomenological Approach."

10 In the discussion of consciousness in Suhrawardi’s Arabic language PI, others are first mentioned in Section 126; In his later, Persian language The Book of Radiance, the inclusion of others in the first person consciousness is discussed in Sections 27 and 44.

11 For discussion of misinterpretations of Husserl's transcendental idealism, see Zahavi, Husserl's Legacy.

12 For more on the perils of rationalism in interpretations of PI, see Louchakova-Schwartz, "Phenomenological Approach."

13 Russell, Problems.

14 Husserl, Crisis.
} 
spirituality (a.k.a. mysticism) ${ }^{15}$ However, as I advocate in this paper, what stands out is not so much his variations on the Greek themes or the deliverables in the form of the philosophy of intuition or newly refined logic, but his way of inquiry in the construction of argument.

Even in the earliest Presocratic philosophy, discussions of relationships between reason and God point to some transcendental concerns, ${ }^{16}$ but the latter remain undeveloped: e.g. in Parmenides, this concern is cancelled by the logic of his own argument. ${ }^{17}$ Some inkling of transcendental aesthetics can be perhaps read into Aristotle's theory of intellection (understanding), according to which "there is an intellect such as to become all things," 18 and then, visual light becomes a metaphor for this function of the intellect. In Islamic philosophy, Avicenna develops his own variations on the theme: the "illuminating" faculty of the intellect functions by analogy with optics. ${ }^{19}$ Thereby, these two seminal thinkers, whose influence on Suhrawardi is well documented, divest themselves from a possibility of transcendental reflection (which stricto sensu begins with Kant) and, instead, adhere to the rationalempirical approach of cognitive psychology. Within the realm of their rational-empirical approach intellection is light only by simile and visual light per se has no special, even less transcendental, function in knowledge. ${ }^{20}$ By contrast, at the junction where Aristotle and Avicenna turn towards optics, Suhrawardi opts for philosophical reflection which reveals the essence of visual light and proceeds towards examinations of relationships between the knowing self and the world. In other words, Suhrawardi turns towards the transcendental problematic.

Suhrawardī's stand-alone "turn" towards the transcendental problematic is even more evident if one compares his argument with another likely strong influence, Plotinus. ${ }^{21}$ Plotinus begins with the structure of the soul and then absolutizes it in a cosmogonic projection; by contrast, Suhrawardì begins with visible light (i.e., the world, in PI, Part 1; Part 2, The First Discourse) and then works towards the unity of its essence with the self (soul) and from there infers the existence of the Absolute (in PI, Part 2). At the core of the construction of the argument in $P I$ is the essence of evidentiality that visible light and consciousness have in common. ${ }^{22}$ By his transcendental treatment of evidentiality, Suhrawardī offers a way of connecting Cartesian and lifeworld tendencies that were left without a systematic unification in Husserl's account. ${ }^{23}$ Consequently, I aim to explicate the phenomenological ontology of the concept of light in The First Discourse of PI 2 and show how Suhrawardi constructs his argument towards the concept of transcendental unity.

In Section 1, “The Phenomenological Reading of Suhrawardi,," I further justify the phenomenological approach in reading PI, including the historical reduction. In Section 2, "Between PI and Transcendental Phenomenology," I explain the relationships between PI and phenomenology by arguing that Suhrawardi tapped into a yet-unexamined aprioristic horizon. In Section 3, "The Thesis of the Evidentiality in Visible Light," I follow PI in temporal extension of its argument. In subsection 3.1, I show light as a condition of possibility for appearances. In subsections 3.2 and 3.3, I test the aprioristic character of Suhrawardī's discovery by examining symmetries between the role of visual light in positing ontological validities and the ontological (causal) primacy of visual light in the construction of knowledge within the transcendental empiricism of science.

In Section 4, "From Visible Light to Awareness," I show the reduction by which Suhrawardi transitions from the object-related evidentiality in visible light to the pure self-evidentiality of subjective consciousness. The explication of evidentiality in both the subject and the world leads to locating the purest expression of selfevidentiality in first-person consciousness, and matures as the recognition of ontological continuity between consciousness and visual light. Further, Section 4 summarizes the logical steps of Suhrawardī's argument of transcendental unity. Section 5, "Last Steps of Suhrawardī's Argument: The Unity of Life and the Character of Knowledge,” follows PI in a discussion of the special ontological status of purified light, i.e., of consciousness.

15 For more, see Marcotte, "Suhrawardi"; Walbridge, Leaven. For criticism of post-Peripatetics, see Walbridge and Ziai, "Translators' Introduction."

16 For more on relationships between pure reason and God in early Greeks, see Miller, "Becoming God"; Whittaker, God.

17 For thinking in Parmenides, see Crystal, "Scope”; for transcendental claims, see Cherubin, "Inquiry."

18 De Anima 3.5 (430a10-17), in Aristotle vol. 1 (ed. Bekker), quoted from McGinnis, "New Light.”

19 See McGinnis, "New Light," 53: "Unlike Aristotle’s account of the active intellect and his comparison of it with light, we see that virtually every feature in Avicenna's account of intellectual understanding has its analogue in his optics.”

20 For rational empiricism in Avicenna, see Gutas, Avicenna. For contrast with transcendental reflection, cf. Kant, Critique, 58-57. 21 Suhrawardī was also aware of the work of the contemporary Islamic philosophers Baḡdādiand Sāvaji (Ziai, "Illuminationism”). 22 Cf. Taguchi, Problem, 206: "Demzufolge gibt es 'für alle Gegenstände eine Anschauungsnähe und eine Anschauungsferne, ein Emportauchen in das helle Licht, das einen inneren Reichtum an bestimmten Momenten herauszuanalysieren gestattet, ein Zurücksinken ins Dunkel, in demalles verschwimmt" ("As a result, there are 'for all items a nearness of intuition and a distance from perception, an emanation into the bright light, which allows to analyze out an inner wealth at certain moments, a sinking back into the darkness in which everything becomes blurred"': cited from HUA, V, 104). Husserl uses the term "light” only metaphorically; e.g., ibid., 40; in Mat III, 95 "seeing” is like by light.

23 For more on Cartesian and lifeworld tendencies, see Luft, "Husserl's Theory." 
This special status of consciousness-i.e., serving as a condition of the possibility of making things evidentconnects with the already discussed evidentiality of visible light and creates the transcendental foundation for empirical knowledge.

\section{The phenomenological reading of Suhrawardī}

It is generally believed that the main feature of the Philosophy of Illumination is so-called knowledge-by-presence, which is immediate intuition of an object whose mode of existence is mental: i.e., "internal" in the terms of the natural attitude. In such intuition, or, in other words, in one's awareness, the consciousness of the knower and the object of knowledge form the ontological unity: the object of awareness appears in awareness by means of awareness, i.e., is a part of awareness itself. A description of knowledge-by-presence in Encylopedia Iranica is knowledge-by-presence is "when any knowing subject (modrek/dānanda) and any knowable object (modrak) dānesta) form 'sameness' by an identity [while] preserving relational correspondence in the generalized domain of knowing (edrāk/dānestan), then, and only then, knowing is actualized, as stated by Sohravardi [Suhrawardī, O.L.-S.]: 'knower, known, and knowing are here one' (al-modrek wa al-modrak wa al-edrāk hāhonā wāhed)."24 Husserl's theory of constitution of consciousness includes a similar concept of intentional objects, which are the real objects which are considered with regard to their givenness in consciousness. The difference between the two theories is in how one understands phenomenal consciousness.

Already in the early Logische Untersuchungen (1913), Husserl recognized that if these two epistemologically different objects, a real one and the intentional one, are ontologically the same object, this fact points to the core of the transcendental problem. He tried to solve this problem first by switching from the natural to the phenomenological attitude and gaining access to the analysis of constitution; and then, in his last unfinished work, The Crisis of European Science and Transcendental Phenomenology (1936), by introducing transcendental reduction and finally solving the problem of transcendentality of knowledge.

If the concept of knowledge-by-presence is taken separately from the rest of argument in PI, the transcendental problem remains unresolved. Making sense for self-knowledge, for religious experience, and within aprioristic essentialism (idealism), the statement of unity of the knower, knowing, and known with regard to knowledge of the world is problematic, unless there is a corresponding transcendental theory-a problem recognized by Yazdi. ${ }^{25}$ However, as I show, Suhrawardi does address this problem, and not via doctrinal statements, but within the flow of the unfolding argument regarding the nature of light in The First Discourse of PI 2. The same approach, i.e. using an extended argument to show the connections between seemingly disjoined lines of analyses, appears in his hallmark syntheses of different intellectual and mystical traditions. Hence, one needs to follow the genealogy of his ideas within the temporal extension of his argument in the text of PI, "genealogy" here having the same meaning as in Husserl's Experience and Judgement, ${ }^{26}$ i.e., as the logic of the argument which leads to emergence of a particular understanding and, thereby, of concepts. Without such an analysis, it is not possible to say exactly which aspects of knowledge Suhrawardī saw as truly aprioristic, and in what sense. Further, abstractions per se, i.e., the mental essences, may count as experiences of a certain quality, with a definitive "what it's like" of thinking; or they may be grounded in particular internal experiences-a set of possibilities all of which require phenomenological clarifications. Hence, Suhrawardì's essentialism is of a special kind, closely tied to the thesis of knowledge-by-presence whose phenomenal intuitionism opens the door to transcendental argument in need of phenomenological reflection.

In the tradition itself, ${ }^{27}$ Suhrawardī is credited with an innovative, original combination of discursive (PI1) and intuitive (PI2) knowledge. ${ }^{28}$ This assumes not merely putting logic and aprioristic intuitionism next to each other in the same book, but creating a whole new argument, with logically coherent and unified steps. ${ }^{29}$ Accordingly,

24 Ziai, "Illuminationism." Note that my style of transcription of Arabic and Persian is more conventional and differs from the Encyclopedia Iranica system which was used by Ziai in the quoted article from Encyclopedia Iranica.

25 Yazdī, Principles, 27-40.

26 Husserl, Experience, 11.

27 Shahrazūrī refers to Suhrawardī’s tradition as "Persian philosophy". This allows him to differentiate between philosophies of intuition and post-Aristotelian philosophy of logic with Greek roots (Walbridge and Ziai, “Translators' Introduction,” $166 \mathrm{n}$. 8).

28 Ibid., xx n. 15. For more on transition from discursive to intuitive knowledge between the two parts of PI, see LouchakovaSchwartz, "Phenomenological Approach".

29 Cf. Carr, “Translator's Introduction,” xxx: “A constant strain through Husserl's career is his disdain for the tendency of some philosophers to conjure up a doctrine of their own simply by an ingenious dialectical combination of the doctrine of others. The true introduction to phenomenology - and thus to philosophy, for Husserl-is to be found precisely by turning away from the 
PI 1 is not just a criticism of logic in itself, but often a reappraisal of Aristotelian or Avicennian categories with regard to their relationship to experience; $;^{30}$ and PI 2, especially sections 107-111, which I discuss below, shows not just the different orders of eide in the mind, but interdependencies between the empirical and the mental. Further, discussion of the nature of consciousness in PI 2 includes a reference to other conscious selves, ${ }^{31}$ thereby referencing the world horizon in which other selves carry constitutive presence. Thus, the philosophical evidence used by Suhrawardī includes experience in two modes: in PI 1, as the empirical ground for deduction of the rational categories; and in The First Discourse of PI 2, as the field of consciousness in which, by means of these same rational categories, he can analyze the transcendental cooperation between presentive intuition and visible light. ${ }^{32}$ Then, further on in PI 2, he turns to analyses of the structure of the mind. Reason thereby becomes grounded in presentive intuition, and presentive intuition becomes grounded in "external" empirical data from the world. In modern terms, Suhrawardi is concerned with the possibility of the transcendental structure of experience, i.e., the means consciousness has at its disposal in the construction of knowledge of the world.

Understanding these aspects of $P I$ faces two constraints: first, the masking of individual insight by the cloak of tradition, and second, the impossibiliy of understanding presentive intuition by means of post-Enlightenment rationalism..$^{33}$ This doesn't mean that Suhrawardī's intuitionism is not rational, but rather, that his rationalism is of genealogical character and is justified by reference to experience, while scientific rationalism doesn't seek justifications and, despite its logical character, takes its own categorizing and implicit ontology for granted, thereby becoming a de facto idealism. ${ }^{34}$ Hence, a phenomenological ontology of rational intuitions will be, by the default of interpretation, reduced to a doctrine, and that doctrine will have to be fitted into the alleged historical context of tradition, etc.

Like many philosophers before and after, Suhrawardī draws on the work of his predecessors. ${ }^{35}$ Husserl commented on such situations as follows: ${ }^{36}$

Every historical philosopher performs his self-reflections, carries on his dealings with the philosophers of his present and past. He expresses himself about all this, fixes through this confrontation his own position, and thus creates a self-understanding of his own deeds in accord with the way his published theories have grown up within him in the consciousness of what he was striving for. But no matter how precisely we may be informed, through historical research, about such "selfinterpretations" (even about those of the whole series of philosophers), we learn nothing in this way about what, through all these philosophers, "the point of it" ultimately was, in the hidden unity of intentional inwardness [innerness, O. L.-S.] which alone constitutes the unity of history.

In this scheme of things, "trailblazers"-original thinkers (Husserl mentions Socrates, Plato, Aristotle, the Sophists, Descartes, Hume, and Kant)-occupy a place different from that of "perfecters." “ Trailblazers” come up with the new and essential rationalities which form the transtemporal unity of knowledge. Historical facti.e., the narrative-is "external" to this unity. ${ }^{37}$ In the unity of knowledge, the key insights relate to tradition only secondarily. Primarily, they come from individual modes of thinking-hence another reason to apply phenomenology.

My approach includes explicating the phenomenological ontology of Suhrawardì's concept of light in The First Discourse of PI 2 and placing this ontology within a regard for transcendental phenomenology to which Suhrawardī's treatment of light provides an additional infusion of sense. Although this implies some comparisons,

opinions of philosophers and by turning toward 'the things themselves' (zu den Sachen selbst)."

30 Cf. Rappe, Reading Neoplatonism.

31 PI 2, 126, 86.

32 Suhrawardī's treatment of consciousness sustains distinctions between "external" and "internal”. Husserl overcomes these distinctions already in volume II of Logische Untersuchungen.

33 For critique of rationalistic interpretations of PI, see Louchakova-Schwartz, "Phenomenological Approach."

34 For the well-known criticism of rationalism, see Merleau-Ponty, Phenomenology of Perception.

35 For examples, see PI 1, 52, 72.

36 For the quotation, see Husserl, Crisis, 72-73. By the hidden unity of intentional innerness, Husserl meant the essential, apriori structures of consciousness that bear on the diachronic reconstitution of socio-geo-historical intentional worlds (Steinbock, “Generativity,” 298).

37 Constitutively, narrative belongs to the problem of intersubjectivity. "In this regard we speak of the "interrsubjective constitution' of the world, meaning by this the total system of the manners of givenness, however hidden, and also the modes of givenness, however hidden, and also the modes of validity for egos; through this constitution, if we systematically uncover it, the world as it is for us becomes understandable as a structure of meaning formed out of elementary intentionalities.... To go back to the intentional origins and unities of the formation of meaning is to proceed towards a comprehension which, once achieved (which is of course an ideal case), would leave no meaningful question unanswered" (Husserl, Crisis, 168). 
the project in itself is not comparative but rather focuses on the examination of the conditions of possibility for transcendental modes of knowledge. To explicate these conditions of possibility in PI, I have to apply Husserl's historical reduction, that is, suspend traditional interpretations provided by the historical narrative. This by no means is meant to uncover some ahistorical, universal essence, but simply removes the claim "valid only for a particular historical time and circumstances," 38 shifting attention away from ossified historical narrative and the empirical entities of tradition to deep layers of consciousness. ${ }^{39}$ Similarly to better known phenomenological and transcendental reductions, historical reduction is also a suspension of non-essential [not related to the structure in question] components of sense; in each case, the horizon of analysis determines how exactly this or that reduction will be performed. In the case of historical reduction for the analysis of PI, I will not task myself with examining, e.g., whether Suhrawardī's ideas are uniquely his or borrowed, and how well they fit or do not fit within the context of reception of Avicenna's philosophy in post-Avicennian Islamic society, etc. - topics of undoubtedly great importance but outside of the scope of concern of this paper. Historical reduction allows me exactly to suspend such concerns and focus on whether and how the genealogy of knowledge in PI contributes to the intentional unity of knowledge that mediates the ongoing self-renewal of philosophy over the course of history (cf. Husserl's quote above).

\section{Between PI and transcendental phenomenology}

Both PI and phenomenology may be traced back to early Greece, ${ }^{40}$ and both begin with the analysis of appearances in the natural attitude and then progress towards reductions. ${ }^{41}$ However, the trajectories of their thinking are different, and thereby create a nice possibility of complementarity.

According to Prier's comparative analysis of ancient Greek textual vocabulary, the implicit visual reference in the ontology of the natural attitude in Homer undergoes a switch to hyletic reference in Aristotle. ${ }^{42}$ Visual reference means that things are "there and this" for us by means of natural light, as phainomena: literally, as "lighticles." In Aristotle, things exist as forms and material substances. ${ }^{43}$ Notably, because Prier's analysis is logocentric, it is not limited to a particular source, but is relevant to an epoch. ${ }^{44}$

In Europe, especially after Galileo and Descartes, construction of knowledge became centered around spatiality and the ontology of localized bodies: that is, it picked up the hyletic reference and combined it with mathematization of form. Visual reference, i.e., reference to the appearances-bringing light, became limited to largely post-Neoplatonic religious contexts and acquired metaphorical or allegorical character. In contrast, even though Islamic philosophers absorbed Greek rationalism, ${ }^{45}$ they did not experience the nascent influence of scientific objectivism, thereby keeping the doors open for the ontology of appearances. I'd like to suggest that between the well documented impact of the Zoroastrian dualism of light and darkness and the reading of Neoplatonic and early Greek philosophical texts, Suhrawardì' retained much of the original Greek reference to light, whereas phenomenology, despite the epoche ${ }^{46}$ became incentivized to analyze Erlebnis with regard to the centrality of embodiment. ${ }^{47}$

Here is how this situation bears on the classical phenomenological argument regarding the nature of transcendental knowledge. Looking back at the development of phenomenology, in his late work, The Crisis, Husserl remarks: "[S]elf-evidence (that petrified logical idol) is made a problem for the first time [in Logische Unterschungen, written in 1913], freed from the privilege given to scientific evidence and broadened to mean original self-giving in general..." 48 That original study of self-giving leads to the theory of intentionality and intentional objects. All intentional objects (of the world) are indexed with regard to belief-contexts and at the same time have a relationship of identity with real objects-i.e., they exist. (Such is the only way Husserl

38 For the quotation, see Carr, Phenomenology, 248.

39 Thanks to Espen Dahl for this formulation.

40 For more on light and visuality in ancient Greece, see Kampakoglou and Novokhatko, Gaze; Prier, Thauma.

41 Louchakova-Schwartz, "Phenomenological Approach".

42 Ibid.

43 For more, see Long, "On Touch.”

44 For explanations of the role of logocentricity in the findings, see Prier, Thauma, 222-223.

45 Gutas, Avicenna.

46 Cf. Husserl, Crisis, 237: “This is within our freedom [to suspend ontological judgment]."

$47 \mathrm{Cf}$. "The natural science of the modern period, establishing itself as physics, has its roots in the consistent abstraction through which it wants to see, in the life-world, only corporeity" (ibid., 227).

48 Ibid., 234; also Logical Investigations, V: II, chap. 4, §32. 
approaches the concept of existence. $)^{49}$ The intentional aspect of existence comes with the "inexhaustible multiplicity of perceptive profiles," which contain both transcendental (i.e., embodied and intersubjective) and immanent (reelle, i.e., internal to consciousness) aspects. ${ }^{50}$ This is why in The Primacy of Perception MerleauPonty says: "[T]he perceived thing itself is paradoxical; it exists only in so far as someone can perceive it," 51 meaning not that the real being of a real object depends on perception, but rather that the perceived object comes in perceptual profiles and thereby is not foreign or completely transcendental to her who perceives: the transcendental-immanent character of perception always contains a surplus of meaning which makes things into presentations for the constituting ego. Simply stated, presentations are there only because they are meaningful; Husserl retains this position up to the very end. Since meaning is intersubjective, it follows that the appearances carry the constitutive presence of others in our shared participation in the world: that is, via embodiment. Hence, the Kantian "if a world is to be possible" is conditioned on embodiment and the constitution of intersubjectivity. Even though different versions of phenomenology carry slight differences in their approach to the embodiment of the ego, the weight of the argument is always on embodied (inter)subjectivity, which in different ways becomes a condition of possibility for presentation.

This leaves out concern for the foundational conditions of the possibility of knowledge. ${ }^{52}$ Husserl and Henry take up this problem in different ways. Husserl explicates the horizon of abstracted "original knowledge," which he terms "pure seeing"; ${ }^{53}$ this "seeing" is not visuality but cognition in a purely theoretical attitude, i.e., eidetic intuition. ${ }^{54}$ This posits the knower in relation to the world, but not within the world: ${ }^{55}$ like its predecessors in the history of thought, the soul and "internal" psychic life of the real psychophysical being, the ego finds itself, once again, in opposition to the world. One would think that the analysis of constitution would have to eventually resolve into understanding how exactly, ontologically, the ego, which is embodied within the world, gains for itself the capacity to constitute the world. This becomes the central problematic of Husserl's mature works in transcendental phenomenology, but constitute all you may, the absolutely transcendent world of the natural attitude remains unreachable by the immanence of this "miraculously" correlated cognition.

In another kind of phenomenology, Henry both assigns the possibility of knowledge to the ego itself, ${ }^{56}$ and strips away the ontological autonomy of transcendence by grounding it in absolute immanence. ${ }^{57}$ Against Husserl's "pure seeing”, he explicates a more primordial a priori by suggesting that "[E]very actual and potential phenomenality first becomes a phenomenon, and it is only on the condition of a prior realized and given phenomenality that any phenomenon whatsoever can be become a phenomenon in it." 58 This fundamental "selfappearing of appearing... must be non-intentional and, since intentionality is tied to visibility in the general sense of perception (or representation), invisible." ${ }^{59}$ Thus, the hyletic reference reaches its absolute philosophical climax: the invisible, self-affective impressional phenomenological "stuff"-i.e., the principle of flesh in its earlier philosophical incarnation $s^{60}$-is discovered to be the foundation of all sensorium, all constitution, all eidetic seeing, and all appearing. The phenomenological "matter" of material phenomenology is not the same as Aristotle's or Husserl's hylē, but it is within the reach of the hyletic reference, as ontology's hyletic metaphor: via material phenomenology, hyletic metaphor extends into the phenomenology of life and partakes in its concept of essence.

In the moment that Serban calls "the shadow of Husserl,"61 non-intentional phenomenology faces the problem of reflection: What would be the ways of the construction of knowledge in the appearing of intentionality,

49 Pietersma, “Husserl's Concept,” 311-312.

50 For perceptive profiles, see Veríssimo, "Husserl's Theory."

51 Merleau-Ponty, Primacy, 16.

52 Most radical realistic critique of phenomenology suggests that phenomenology abandons the question of how cognition can get at, or know, the object that transcends it (e.g., Sparrow, End, 29).

53 Husserl (Ideas I, 382) states that in the analysis of internal consciousness of time, it is necessary to account for an atemporal, preintentional horizon of consciousness, metaphorized as "flow" (that is, as a continuity creating a background for constitutive moments of protention and retention in the time-consciousness). This "pure seeing," which is also equated with "absolute subjectivity," serves as an absolute constitutive a priori. Therefore, we must concur that "pure seeing" is a condition of possibility for all forms of noēsis.

54 Dastur, "World," 27-28.

55 Cf. Husserl, Crisis, 183.

56 Henry, "Ontological Destruction."

57 Henry, Essence.

58 Henry, Philosophy, 22.

59 Seyler, "Michel Henry."

60 For more on flesh and the body as the substratum of primary impressions, see Henry, Philosophy.

61 Serban, "Beneath Time." 
since its appearing is conditioned on the being of phenomenological materiality? This problem unsolved, the hyletic metaphor appears to win altogether: if one takes the path of constitutive (intentional) phenomenology, the world is known via intersubjectivity's bodily transfer; and if one takes the path of Henry's nonintentional phenomenology, ${ }^{62}$ by essence the world and the self are manifest always and fully, but not really known. Poignantly, Henry states: "The world to which we have access is indeed different depending on whether it is known by ideal geometry (as Galileo believed), by the intellectual intuition of the pure understanding (as after him Descartes and classical philosophy thought) or if it is on the contrary a question of an originally sensible world at every moment resulting from the concrete performances of our various senses." ${ }^{63}$ Perhaps, such multiple ways of understanding and presentation are necessary; perhaps, to know the world, one needs it all. ${ }^{64}$

After one becomes aware of the "hidden layers" in constitution and of the nonvisual a priori, the world comes back with the unrelenting strength of visuality. "[F]rom the perspective of the one who has already performed the reduction, leaving the natural attitude is in itself a problem with its own serious difficulties," says Luft; ${ }^{65}$ the stubborn question of transcendental correlation does not become less stubborn. In the phenomenological discussion of visibility and invisibility, left behind are the concrete, nonmetaphoric roots of the original Greek visual reference, which, by etymology of phainomenon, captures the character of subjectivity's access to the world. We routinely use sentences such as "Consciousness and its process of constitution is better interpreted as recognition" or "[T]he body is the most complicated logic that I will ever see because I cannot fully see it," 66 and so on, upon implicitly assuming that "seeing" must be a figurative term. Then there emerges a strange theoretical situation in which "pure seeing" has to either be grounded on itself (as in Husserl) or have an origin in something essentially different and thereby incapable of individuation, i.e., in the invisible of Henry. ${ }^{67}$ In these two discussions, the passive and concrete self-evidentiality in the intuition of the world either completely slips off the radar (in constitutive phenomenology) or is identical with the whole of manifestation at the expense of the actual predicament of the individual knowing self. This strangeness suggests a missing a priori, a metaphysical horizon that would account for the possibility of self-evidentiality per se. This further requires a return to the prescientific natural attitude and an examination of the concrete structure of perception, on the one hand, and the real world, on the other: that is, a return to the concretum of realistic seeing.

Even if seeing is something we $d o,{ }^{68}$ something that the ego keeps "sway over," the condition of possibility for visibility does not pertain to the activity of the ego. If, as in Kant, "a world is to be possible," it has to contain the possibility of such possibility within itself. Interpreting Suhrawardī, it is only because we ourselves enjoy being possible within the world that we can claim the transcendental as our own ${ }^{69}$. Being possible means first being in the world's horizon of visible light. This light requires no adumbrations and no constitutive presence of others; appearance by the body is conditioned on the primary appearance of light. Because we are in the world, we are endowed with the same essence of self-evidentiality as is visible light: immanence begins with the latter, not only because of the self-evidentiality of its essence in us, but because of the foundational ability of the universe to be visible.

One of the advantages of taking Suhrawardi seriously is that because of his strict emphasis on givenness by light, he pushes the understanding of experience beyond the usual boundaries of our "dumb empirical paradigm."70 This is essential not only for the clarification of experience, but for the construction of transcendental arguments. As noted by Putnam, a response to skepticism depends on how pronounced and well understood is the empirical element in the proofs. ${ }^{71}$ But if this is so, without solving the transcendental problem, any empirical grounding of response to skepticism will remain fallacious. The crucial "how is it possible?" of the "empirical” is yet to be clarified. As Husserl noted: ${ }^{72}$

62 Henry, "Phénoménologie."

63 Henry, Incarnation, 118. Emphasis added.

64 For multiple ways of knowing in Plato and Aristotle, see Chapell, "Varieties."

65 Luft, "Husserl's Notion," 3.

66 Costello, "From Other People."

67 For a contrast between evidence-based (Husserl) and invisibility-based (Marion) positions in phenomenology, see Tarditi, "Seeing the Invisible." No such discussions in phenomenology involve the analysis of light per se.

68 Noë and O’Regan, "On the Brain-Basis."

69 Cf. Zahavi, Husserl's Legacy, 175: "World exists-that is, it is-only if Dasein exists, only if there is Dasein. Only if world is there, if Dasein exists as being-in-the-world, is there understanding of being, and only if this understanding exists are intraworldly beings unveiled as extant and handy. World-understanding as Dasein-understanding is self-understanding."

70 For the quote, see Koenderink, "Kalderon,” 1436.

71 Putnam, cited in Stern, “Transcendental Arguments."

72 Husserl, Philosophy, 300, 258-259. 
$[\mathrm{H}]$ ow a play of experiential-logical consciousness is to mean something objectively valid, something valid for physical things existing in and of themselves; why, so to speak, the playing rules of consciousness are not irrelevant for physical things...-all this becomes a riddle as soon as reflection is seriously directed to these questions.

It can be argued that if we still do not have all the answers, this is because, growing out of particular systems of experience, ${ }^{73}$ philosophies committed themselves to limitations of epochē. Growing out of a different system of experience, with a different use of visual reference, Suhrawardì's epoché is different from that of phenomenology, and thereby opens alternatives in solving transcendental problems. To access such alternatives, I approach the text of PI under the already mentioned historical reduction, but this comprises only the first step. The whole of analysis in this paper is conducted under a supposition that $P I$ is a philosophy grounded in analysis of experience. Since the main achievement of phenomenology is clarification of experience, one can use phenomenological understanding of consciousness to interpret, or better, understand the genesis and constitution of Suhrawardi's thought. Specific aspects of the experience of light, which was omitted in phenomenological analyses or reduced to analyses of perception, can nevertheless be placed in context of the most general phenomenological theory of consciousness precisely because this theory is de facto an unveiling of the universally present structures of consciousness and thereby creates a frame of reference for any analysis of experience. Thus, in the next section, I explicate Suhrawardi's thesis of "being evident is its being light"74, and then examine whether and how this thesis applies to different strata of experience, thereby showing its truly universal nature.

\section{The thesis of the evidentiality in visible light}

$P I$ consists of an introduction with the methodological overview of Suhrawardi's approach in PI, and two parts. Part 1 (PI 1) includes a criticism of logic and natural perception, and Part 2 (PI 2) contains analyses of light in appearances of the world and within subjectivity. In a stunning and explicit parallel reminding one of volume 2 of Husserl's Logische Unterschungen, Suhrawardī introduces his approach by stating: "Just as by beholding sensible things we attain certain knowledge about some of their states and are able to construct valid sciences like astronomy, likewise we observe certain spiritual things and subsequently base divine sciences upon them.."75 This establishes a descriptive-psychological, empirical-phenomenological attitude to experience within which a distinction is made between the empirical evidence of the senses (which can be external or internal, O. L-S.) ${ }^{76}$, and evidence that is spiritual, i.e. nonsensory but nevertheless empirical and thereby can be "observed" 77 , i.e., given as an appearance one subjectively lives through. In Part 2, the empirical-phenomenological attitude acquires transcendental character in the analysis of correspondencies between the objects of the world and the structures of awareness; it also acquires similarity with the phenomenological attitude due to the focus on evidentiality of appearances. This "proto-phenomenology" includes analyses of the reelle objects of consciousness and of selfawareness. ${ }^{78}$

The introduction identifies intuition (meant as awareness of presentations and as eidetic intuition) as the medium of knowledge. ${ }^{79}$ Intuitional knowledge is meant to stand not by itself but in dialectics of "proofs and clear evidence to champion it,"

73 For more on the systems of experience, see Allen, "What Is Husserl's First Philosophy?”

74 PI 2, 117, 81: " wazuhūruhu nūriyyatuhu".

75 PI, "Introduction," 6, 4.

76 Cf. Husserl, Logical Investigations, 6: “...for Berkeley ideas are the things perceived, i.e. contents of consciousness in the sense of things we really (reell) live through".

77 In some forms of spirituality, e.g. early Christian mysticism or Indian Tantra, impressions of internal "subtle" senses comprise an important part of experience. While for Suhrawardi thought is definitely an experience, his position towards subtle senses needs further clarification.

78 Cf. three concepts of consciousness proposed by Husserl (Logical Investigations, 81): "1.Consciousness as the entire, real (reelle) phenomenological being of the empirical ego, as the interweaving of psychic experiences in the unified stream of consciousness. 2. Consciousness as the inner awareness of one's own psychic experience. 3. Consciousness as a comprehensive designation for 'mental acts', or 'intentional experiences', of all sorts.”Suhrawardì's approach presupposes examinations of consciousness as aspects of (1) and (2), but not as intentionality (aspect 3).

79 PI, "Introduction," 2, 1. Here, I ground understanding of Suhrawardì's terms in the first person experience of consciousness: "intuition" doesn't mean a psychological foreseeing of events, but refers to presence of objects in consciousness, i.e., perception in the Merleau-Pontian sense.

80 Ibid., 4, 2; Also 3, 2: "I did not first arrive at it [the Philosophy of Illumination] through cogitation; rather, it was acquired through something else [insight or direct intuition of essences]. Subsequently I sought proof for it, so that, should I cease 
soul." ${ }^{81}$ Intuitions themselves being a subject of reflection, Suhrawardī's methodology presupposes reflection on both intuitional knowledge as such and on how this intuitional knowledge is given, including experiences of the spiritual kind.

The transcendental concerns appear already in The Third Discourse $(P I 1,104,73)$ in the discussion of "the problems of vision, forms in mirrors, and the imagination", in which Suhrawardi shows that the theory of "imprinting" (i.e., representationism) is insufficient to explain the empirical seeing. The solution will emerge in PI 2, in which he will switch from the psychology of perception to transcendental reflection on light. This reflection will show light spanning the subject and the objects of knowledge as the self-evidential condition of possibility for any perception. To that end, PI 1 examines more particular instances of perception and knowledge, such as a distinction between definition (a description of mental essence) and a description of the real thing. The distinction between understanding (by essence) and real objects is in contrast with the situation in which simple sensations such as luminosity and sound have an identity of their actual form and their form "in the mind." 82 This example of self-evidence in the pregiven paves a road to the discussion of the ultimate self-evidentiality of light and its sameness in objects and in self-awareness. ${ }^{83}$ As noted by Walbridge and Ziai, ${ }^{84}$ in PI 1 Suhrawardi shows that sensory experience and mental eide are complementary in knowledge; however, their radical empirical/ ontological divide is resolved only in PI 2, via the transcendental reflection on light. PI 1 ends up with a refined concept of unity ${ }^{85}$ which promptly advances the argument towards PI 2.

\title{
3.1 Visual light and dusky substances
}

\author{
Reflection in PI 2 begins with:
}

[107] Anything in existence that requires no definition or explanation is evident. Since there is nothing more evident ('azhar) than light, there is nothing less in need of definition." 86

But what kind of light is the light in question? Section 107 suggests at least three possible readings: first, in the empirical-phenomenological attitude, light as externally visible light; second, in the same attitude but inclusive of internal experience, light as the Plato-esque light of the mind, which, depending on whether one means internal experiences of luminosity or the levels of emanationist mental hierarchy (or both), may or may not be metaphorical; ${ }^{87}$ and third, in abstraction, light as a metaphor of existence. From the note on ontological dependencies and independencies (108), and the discussion of dusky substances, barriers, and how these are illumined by light (109-111), it becomes apparent that section 107 refers to physically visual light, which is neither reduced to a sensation nor metaphorized as mental essence or metaphysical being-essence. Suhrawardi specifically clarifies the manifest visuality of light in question: ${ }^{88}$

contemplating the proof, nothing would make me fall into doubt."

81 For the quotation, see ibid., 6, 4. For the discussion of evidence in PI, see Louchakova-Schwartz, "Phenomenological Approach." For grounding logic in the analyses of experience and consciousness in Logische Untersuchungen, see Haaparanta, "Analysis.” For example, PI 1, 24, "What Pertains to Syllogism,” 21, stays within pure logic, whereas ibid., 106, "On Unity and Multiplicity,” 75, references actual existences.

82 PI 1, 105, 74.

83 Cf. Üçer, "From Identity to Representation,” on identity and representation in Aristotle and Avicenna.

84 PI 1, 180 n. 58.

85 PI 2, 76.

86 zăhir, translated by Walbridge and Ziai as "evident”, also means exoteric, revealed, fully manifest, as opposed to bațin, hidden or esoteric. In the exegesis of the meaning of Qur'anic verses, these terms are applied to the character of knowledge (Heath, Allegory, 182), also in Sufi terminology as defining the modes of divine self-revelation (ibid.,190, 199; also, Lawn-i zuhür). In Sufism, $z \bar{a} h i r$ refers to direct (presentive) intuition of God as opposed to indirect mental knowledge. Likely, Suhrawardi marries Sufi focus on experience with the knowledge-related meaning of the term; interestingly, his use of the term is closest to the Ismaili metaphysics of al-Mu'ayyad fi'l-Din Shīāzi described by Nasr, General Introduction, 11.

87 Cf. Philo (ca. 20 B.C.E. - 40 C.E.): "We see two things, the sensible form and the light which makes it visible. But we should not know that we saw the light unless we saw the form. So the intelligence sees Being, by light given by the One. It must turn away from all objects, and contemplate this light. But the analogy of the eye will carry us still further. For the eye has light in itself-that light that you see when you squeeze your eyelids. The intelligence must concentrate itself on this inner light” (Bigg, Neoplatonism, 281).

88 PI 2, 77. 
[109] A thing is either light and luminosity in its own reality, or is not light and luminosity in its own reality. The meaning of "light" and "luminosity" are the same here, for I do not use these in a metaphorical way, as when "light" is used to mean that which is evident to the mind, though even such usages do [in the end] derive from this light. ${ }^{89}$

Up to section 112, Suhrawardi discusses the ontology of visual appearances according to which the things appear by light which is superadded to dusky substances, illumines their surfaces (barriers)-magnitudes, and makes them be "there". In 112 (see below), Suhrawardī performs a specific reduction (jarrada) and switches from the analysis of the world to the analysis of consciousness. As is well known, in the natural or empiricalphenomenological attitude the presence of consciousness is obfuscated, ${ }^{90}$ and the mind appears only in the form of internal psychological experiences; consequently, all analyses till section 112 are de facto investigations of the objects of the world and are meant to show them in relationship to visual light. ${ }^{91}$ In itself, light is not an object (hence "light and luminosity"), but it is superadded to the objects; metaphysically speaking, light is a principle of self-evidentiality which, in relationship to the objects of the world, acquires the status of visual light.

In PI 1, the luminosity of light belongs to the sensorium. However, such a meaning belongs to natural scientific thinking, from Empedocles on, when the reference to visual light becomes less and less a reference to appearances and more and more a category of perception: ${ }^{92}$ an explanatory determinant of the chromatic hues, ${ }^{93}$ and "a state that the medium is in when it is actually transparent." "94 But in the earliest mention, in Homer and his contemporaries, a prescientific reference to light would be a reference to light in the lifeworld: ${ }^{95}$ in the morning, "one first sees the light of day...; its emergence involves an intimate connection between the life of man and the purpose of the gods." ${ }^{96}$ Thus, section 107 abstracts this visible/visual light with regard to it being "absolutely manifest" and a fully known principle which is identical with its essence.

Against the phenomenological idea that "the kind of evidence proper to the perceived, the appearance of 'something,' requires both this presence and this absence,"97 Suhrawardī explicates not just pure presence, not just immanence, but absolute, unalloyed evidentiality which is not dependent on the partnership between presence and absence. Further, in section 109, in the discussion of the construction of object-appearances through super-adding light to them, light and the invisibles (dusky substances) are not parts of a whole: these are not ontologically neutral equals as are, e.g., the parts of the unities of meaning under the phenomenological reduction, or parts of expressions in the empirical-phenomenological attitude. ${ }^{98}$ The invisibles are substances, not forms. The individual forms (barriers) of these material substances (dusky substances) are exactly what light illumines and thus makes it possible for them to be perceived and thereby "enter" into existence: the presences of substances are conditioned on the presence of light whose mode of presentation is conditioned only on itself; these two are not co-constructed or co-constituted, and they are not mutually or dialectically interdependent. Rather, one is dependent on the other.

If we consider sections 109-111 as a phenomenological ontology of appearances in its own right, these sections de facto suggest that "the natural, anthropological subject-object attitude, the psychomundane attitude," 99 maintains the possibility of the world by the evidentiary vigor (intensity) ${ }^{100}$ of its appearance. In this beginning of transcendental discussion, the evidentiality of the world is identical with the absolute, positive self-givenness of visible light, in which perceptual absences appear by light, and not by themselves or by contrast with the darkness of nothingness - thus resolving Parmenides' paradox of negative existences. Further, Suhrawardi will extend the analysis of the phenomenal continuity of the self-givenness of visible light in the objects of the world

89 Further in support of the visual character of light in 107-109, cf. 109, "light" and "luminosity", with the frequent reference to luminosity as an aspect of visual perception in Greek philosophy: e.g. Hoeppe, Why the Sky, 14, “...to ancient Greeks, including Aristotle, luminosity was more important than hue in characterizing color". Later in the text of PI 2, after reduction in 112, Suhrawardī moves onto the analysis of the "light" of consciousness and stops using the term "luminosity".

90 This is exactly why in Logical Investigations Husserl introduces phenomenological reduction: to bring to the forefront the facts of consciousness.

91 Cf. Husserl, Logical Investigations, v. 2, Part 1, Investigation III.

92 Rudolph, "Sight."

93 Kalderon, Form, 152.

94 Ibid., 53.

95 Cf. Husserl's universal reduction of scientific objectivism, Crisis, 198-213.

96 Snell, Discovery, 38.

97 Merleau-Ponty, Primacy, 16.

98 For unities of objects in the phenomenological-empirical attitude, see Husserl, Logical Investigations, Volume 2, Investigation III. For unities of meaning under phenomenological or transcendental reduction, see Husserl, Meditations.

99 Husserl, Crisis, 248.

100 For the discussion of intensity, see PI 1, 76, 54. 
into analysis of self-awareness, and shape the idea of the metaphysical unity of essence between the two kinds of light, in the world and as self-awareness (both discussed in Section 4 below). Hence, section 107 contains the central thesis of the whole of Suhrawardi's transcendental argument.

The concern for evidentiality creates a reduction of presentations towards a new aprioristic horizon: ${ }^{101}$

[117] If you wish to have a rule regarding light, let it be that light is that which is evident in its own reality and by essence makes another evident. It is, thus, more evident in itself than anything to whose reality being evident is superadded.

Empirically, outside of special spiritual training that visually separates pure luminosity from the objects it illumines, one doesn't see light per se, ${ }^{102}$ but only as a derivative of objects appearing visually: if there is no visual light, nothing is seen. Thereby, the aporistic horizon in 117 (i.e., the abstraction of light to the principle of evidentiality) must participate in the constitution of meaning. In the next section, I will examine this possibility under the phenomenological reduction that gives access to an "experience in a sense of pure phenomenology, "103 i.e., as intended by the ego.

\subsection{Visual light in the constitution of ontological validities}

Since visible light serves as a horizon of possibility for all the forms, it follows that within our perceptual awareness of the world, there exists an indivisible, immutable certainty of its visual character: things appear illumined by light, but "light" per se is not a real world-object, and thus, even though it gives intentional objects, it cannot be an intentional object in the same sense as real world-objects can. According to Husserl, ${ }^{104}$ "[Intentional objects] are not a part of the intention, but are something which is meant in it, its particular meaning, and this in modalities which only have meaning for something like meaning." One of the modalities that has meaning only for meaning is the modality of ontological validation: "the world as if [the] sciences did not yet exist, the world precisely as life-world, just as it maintains its coherent existence in life through all its relativity, as it is constantly outlined in life in terms of validity." 105 Ontological validation of the kind "this is there" depends on light and must accompany intentions directed at all the visible objects, but it is an intention devoid of ordinary object-fulfillment. It simply co-emerges with every visual percept: not being an object itself, light is intended as a component of the ontological validity of all things visible "outside" of me. The light-intentionality lends itself to the constitution of the ontological validity of the world, and only via it, to the constitution of perception (e.g., primal impression, etc.) as such.

\subsection{Light according to transcendental empiricism}

The other ontological signification of light takes place under the attitude of transcendental empiricism, i.e., within science. This is not to say that the findings of science contribute to phenomenology (cf. "discontinuity thesis"): ${ }^{106}$ there is no obvious isomorphism between the phenomenology of perception and the physics of light. However, if one considers light as a phenomenological limit-concept in the valuation of existencies of objects, there is a simple symmetry between Suhrawardi's ontological explication of light and the physics of sight and light ${ }^{107}$ which is "objective", i.e. independent of our cognitive acts. ${ }^{108}$

For commensurability, I will take the data of science out of the empirical-phenomenological ontology of the scientific attitude and refer to the same entity in the attitude of phenomenological reduction that reveals the transcendental character of scientific knowledge. Under the transcendental character of scientific knowledge,

101 PI 2, 81.

102 For a spiritual training of the capacity to perceive visual light separately from objects, see Antonov and Vaver, Complexnaya Systema.

103 Husserl, Investigations, 82. My thanks to the anonymous reviewer who suggested that I provide additional explanations on the use of phenomenological reduction.

104 Husserl, Crisis, 242.

105 Ibid., 216.

106 Kee, "Phenomenological Reduction."

107 The term "transcendental empiricism” appears in Husserl, Zur phänomenologischen Reduktion.

108 Cf. the genealogy of formal ontology in Husserl, Investigations: in logic, we only appropriate the state of affairs in the objects where the relationships between objects imply unity independent of our cognitive acts. 
one understands the act that science attempts to deliver "objective laws" of reality which in itself is transcendent to the ego, as the world "out there." Under the phenomenological reduction to pure meaning, science reveals the transcendental horizon of its empiricism. Hence, both Suhrawardì's principle of visual light as self-evidentiality in appearances and light under the transcendental empirical attitude of science belong to the transcendental horizon opened by reduction, and can be compared within this horizon with regard to their respective meaningstructures generated by the transcendental ego.

Suhrawardī's argument begins with visual light because visual light is the most evident of all things. Likewise, visuality (sight) dominates perception. Ninety percent of the information that the brain absorbs is visual. The visual cortex occupies an astonishing thirty to forty or, according to some sources, fifty percent of the cerebral surface area. ${ }^{109}$ Visual information is processed sixty thousand times faster than text. People remember only twenty percent of what they read and ten percent of what they hear but retain eighty percent of what they see. ${ }^{110}$ The dominant character of visual perception must have something to do with the absolute self-evidentiality of light, but in the phenomenological analyses of perception, this dominant character of visual cognition doesn't stand out and has not been considered with regard to evidentiality (Selbstlichtkeit).

Further, Suhrawardī suggests differentiation between superadded light in appearances and pure light: “[111] that which gives them [the invisible dusky substances] their lights [i.e., their evidentiality] must be something other than the barriers and dusky substances [in themselves]."111 The retina has two kinds of cells, and one kind, the rod cell, is specialized for the perception of white light. Thus, the retina differentiates between perception of light and darkness, and perception of colors. What these cells "perceive,"-or, rather, receive-is a current of massless photons, which exist only as they move with the speed of light. By hitting the biomolecules of the retinal cells, this current gets converted into an electrical signal passed into the brain and serving as a visual "condition of possibility" for other aspects of seeing: e.g., colors. ${ }^{112}$ Exactly what happens in this process is not clear; ${ }^{113}$ nevertheless, in their respective attitudes both visible light and light as a simple physical system serve as a condition of possibility for perception.

Further, the speed of light, which is the same as saying "light," because light exists only as the motion of photons at the speed of light, delimits causal relationships between all other objects in the visible universe. This is hardly physics but, rather, a simple observation: if things are "there" by light, everything that moves faster than light will become simply "not there," because light will not be able to catch up with it in order to illuminate it. Equations describing movement at a speed faster than light "break down into mathematical singularities, where physical properties can’t be defined." ${ }^{114} \mathrm{Or}$,“[u]nder the special [theory of] relativity, if something travels faster than the speed of light, it goes backwards in time. Such a proposition could interfere with the basic rule that cause precedes effect, called causality." 115 In effect, there would be two different universes, one where everything moves slower than light and another, where everything moves faster, with completely different laws of physics. Hence both in the analysis of visual light according to Suhrawardī, and in the transcendental empirical theory of relativity, light serves both as a condition of possibility for the universe as we know it and as a condition of possibility for reason as we know it: i.e., the reason whose logic is coordinated with the acting laws of the universe. This determination of causality by the speed of photons, which are the same photons that hit our retinas in the process of generating visual consciousness, "plugs" human beings into the very organizing principle of the universe.

It follows that as a condition of possibility, light is realized in two ways, visually and, via causal laws of the universe, as the mental essences of comprehending reason. Therefore, one can either think of the human being as a part of the cosmic physical system or one can think of the physical system as extending into the human being and becoming reason. In either judgment, the continuity of light does not simply extend the "inanimate" universe into the "animate" subject but shapes her reason. Physicalistically, light bridges the causal underpinnings of the physical universe with the physicality of vision and consciousness; and in the phenomenological attitude, light "gives" the world into the cognizing subjectivity. What follows is that if I can fully perceive the light by which the world is given to me, my knowledge of the world is not caught up in subject-object divisions or an embodiment that I somehow have to transcend. On the contrary, since the world is by light, and I see by light, the world

109 Max-Planck-Institut, "Quick Links."

110 More, "Why Visual Content Is Crucial."

111 PI 2, 78.

112 Montag, "Vision"; Berg, "Photoreceptor Molecules"; Huth, "Physics."

113 For physics in theories of visual consciousness, see Huth, "New Physics-Based Model." For seeing as a simple physical system, and consciousness as a by-product of such a system, see Tononi and Koch, "Consciousness."

114 Moskowitz, "Hidden in Einstein's Math."

115 Wynne, "Why the Speed of Light Matters." 
is visually immanent to me; likewise, if my self is in the world, and since my self is evident to me, I must be partaking in the full immanence of light.

\section{From visible light to awareness}

As already mentioned, section 111, begins with discussion of visually given bodies: both "dusky substances" and their "dark or luminous state" depend on the superadded light. However, the title of the section, "On the Dependence of the Body in Its Existence upon the Purified (mujarrad, translation mine) Light," suggests that there must be another light, which would be light in itself and not superadded to the objects. To examine light per se, one needs to consider it in its own class of essences-that is, to separate light per se from the light in dusky things it illumines:

[109] Light is divided into light that is a state of something else (the accidental light), and light that is not a state of something else. ${ }^{116}$

The latter light is what Suhrawardī calls nūr mujarrad, the mujarrad light. ${ }^{117}$ Natural, visible light it is no longer: Suhrawardi purifies the existential positing of association with physical nature, tasking himself with the search for light that is not "a state of something else."

[112] Since you know that any light that can be pointed to is an accidental light, then if there is a pure light, it cannot be pointed to, nor be located in a body, nor have spatial dimensions. ${ }^{119}$

This statement echoes Aristotle's De Anima, wherein he differentiates between the soul and the sensorium with its magnitudes. The term Aristotle uses to make the distinction is "asomatic”, i.e., noncorporeal. However, he also places the soul "inside the body"-a move in which "noncorporeality" suddenly becomes internal and by extension acquires a dimension of embodiment. By contrast, in post-Enlightenment rationalism, noncorporeality (i.e., something incorporeal) is meant as pure, abstracted thought, purified even more than the Cartesian cogito with its residual livingness. Consequently, between these two interpretations, section 112 can be read two ways: as an abstraction rendering an essence of eidetics completely empty of any living quality; and as a Cartesianphenomenological kind of reduction leading to consciousness per se and then to the nonintentional, embodied aspect of awareness purified of its objects.

In my prior work, ${ }^{120}$ I argued extensively in favor of the latter. Reading of nür mujarrad as purified awareness (the pure subjectivity) resonates with the whole intuitional focus of PI, with Suhrawardī's consistent work with the evidence, and with the term mujarrad being a passive past participle of jarrada, an exact translation of which is "to lay bare" or "to strip of coverings." Sure enough, it is also a term that was used in the Islamic philosophical tradition to indicate abstraction; but again, there are different kinds of abstraction, and what is meant by jarrada depends on context. Besides, this term has also been used to indicate ascetic austerities, and possibly, meditative absorption. Thus, literally, nūr mujarrad means not "abstracted light," "incorporeal light," or "immaterial light" (all terms that result from reading section 112 as entailing pure eidetic abstraction) but, rather, light subjected to a "stripping of its coverings", i.e., light abstracted from being intermingled with dusky substances, sensorium, and objects en masse. This would be light subjected to the analogue of Cartesian-phenomenological reduction (cf. in Ideas I) and turned into the field of consciousness, which is further reduced to the essence of subjectivity. This, most importantly, is what one observes in the structure of Suhrawardīs argument in PI 2, in which he explicates the essence ("light") of consciousness in The First Discourse, and only afterwards proceeds to analyses of ontological mental hierarchies, in the following discourses.

In the second Cartesian Meditation, Husserl argued that reductions are not just an exercise in logic but are lived by the subject, i.e., they have phenomenal givenness. When a self-reflecting ego undertakes a conceptual abstraction, the field of consciousness changes perceptually, perspectivally, hyletically; in other words, factically. The rearrangement of the phenomenal field following reduction is a dynamic process in which, despite the mutability of the components in the phenomenal field, the structures of rearrangement are predictably defined by dependency on the kind of reduction applied. Suhrawardi first posits the absolute condition of givenness as pure

116 PI 2, 77.

117 See Louchakova-Schwartz, "Phenomenological Approach", for explanations of translation of mujarrad.

118 Cf. Husserl, Philosophy, 299, 258.

119 PI 2, 79.

120 Louchakova-Schwartz, "Phenomenological Approach.” 
light and then seeks this pure light in empirically grounded reduction, by radically dissociating it from all the objects in the phenomenal field. But because of the preceding discussions, this is not just a perception-based differentiation between the seer and the seen, as for example in Vedanta, but a reduction that is at the same time eidetic and changes the way things appear to us. By proceeding from empirical seeing to the essence of visuality, it brings to clarity the essence responsible for all appearances, i.e., the essence of evidentiality and, thereby, of perception. The following quotation from Husserl's Philosophy as a Rigorous Science can be used to explain Suhrawardī's reduction:: ${ }^{121}$

If we bring "color" intuitively to full clarity, to full givenness for ourselves, then what is given is an "essence," and if likewise we bring to givenness for ourselves in pure seeing (perhaps looking from perception to perception) what "perception," perception in itself-that which is identical in arbitrarily many flowing singular perceptions-is, then we have grasped the essence of "perception" in seeing.

Suhrawardi's reduction (tajrīd) also has other connotations. Section 112 also suggests a reversal of the perspectival horizontality of outgoing consciousness, redirecting it towards the irreducible backdrop of all experiences: that is, myself. This backdrop of pure subjectivity can have a variety of relationships with phenomenal consciousness. (Cf. contemporary discussions of me-ness, my-ness, for-me-ness, etc.) ${ }^{122}$ It also can have egological and nonegological "formats." In religious philosophies, this situation was noted and discussed. There are various "maps" of how "pure subjectivity" can be configured, such as the maps of samadhi in Yoga and Vedanta; or the states of divine immediacy in Sufism; or the Rigpa states in Buddhism; or the treatises related to "ego-dissolution" in Vedanta, and so on. But Suhrawardī's primary interest is not in finding the answer to the question "Who am I?" Reduction supports his main agenda, which is uncovering the absolute, indubitable givenness, the pure "evident" that is a condition of possibility for all other givens. Such an evident is self-evident, i.e., "evident to itself” (zuhūru-hu, section 119), ${ }^{123}$ and this allows Suhrawardī to identify it as the self: ${ }^{124}$

[115] If you examine this matter closely, you will find that that by which you are you is only a thing that apprehends its own essence-your "ego." All else that apprehends its own essence and ego shares with you in this.... [T] here is no property with it of which being evident could be a state. It is simply the evident itself-nothing more.

A similar explication of the self is found in Zahavi: ${ }^{125}$

[T] he self is present in experience, not as an additional experiential object or as an extra experiential ingredient (say as some kind of self-quale) but as the very first-personal givenness of experience.... This notion of self is consequently not intended to refer to some persisting and abiding experience-transcendent self-entity, but is rather meant to target and capture the ineliminable subjective and perspectival givenness of consciousness.

And, since this essence is self-evident, the self is self-evident by this essence; Suhrawardi will further demonstrate this common principle of evidentiality in other selves, and in the world.

Here I summarize the steps of Suhrawardì's way into transcendental philosophy:

1. Suhrawardi establishes that there is nothing more evident than visual light;

2. Suhrawardi contrasts the self-evidential character of visual light with the lack of evidentiality in dusky substances, which are not self-evident but proceed from superadded visual light;

3. Suhrawardī outlines phenomenological differences between light per se and what light illumines, i.e., what it makes evident;

4. Suhrawardī seeks the essence of self-evidentiality, the purest evident, nūr mahd mujarrad (purified light). He finds what is evident to itself by itself-i.e., the evident itself-in pure awareness;

5. From pure self-awareness, Suhrawardi moves to the essence of the self: he shows that nūr mahd mujarrad is the irreducible essence of the self (Arabic dhāt).

121 Husserl, Philosophy, 316, 272.

122 Zahavi, "Consciousness."

123 For more on self-evidentiality of mujarrad light, see section 117: “...light is that which is evident in its own reality...”/al-nūr huwwa al-z̧uhūru fì haqīqat... "being evident is simply due to their own reality"/bal zuhūruhā innamā huwwa lihaqiqati nafsihā... "light is evident, and it being evident is it being light"/ huwwa zāhirun, wazuhūruhu nūrriyyatuhu; section 122: "being evident in its own essence"/ zuhūruhu lidhātihi; section 126: (light is) self-conscious/madraku li-nafsihi.

124 PI 2, 80.

125 Zahavi, “Consciousness.” 
6. Suhrawardī demonstrates that both self-awareness and visible light are instances of the same principle, of being "most evident." He calls this principle "Light of All Lights." Whether or not this Light of All Lights is God, or metaphysically-phenomenologically understood life, is open for discussion.

\section{Last steps of Suhrawardīs argument: The unity of life and the character of knowledge}

In The First Discourse, the self $(d h \bar{a} t)$ is in two kinds of relationships, to itself as self-awareness and to the objects as object-awareness, as is also acknowledged by Frankfurt: " in addition to illuminating whatever other things fall within its scope, [self-awareness] renders itself visible as well." ${ }^{126}$ In the predominantly and primarily givenas-visual universe, visual light also manifests the same two kinds of relationships, to itself in its own luminosity and as a condition of possibility for visual appearances of objects. The relationship between the self and visual light also has a dual character: on the one hand, light gives the external objects to the self and thereby is itself external, but on the other hand, it is appearing not as an object but via colors and shapes that consciousness assigns to the objects by means of this very light. In the final count, visual light depends on consciousness, as in Howell and Thompson: "phenomenal me-ness cannot merely be a metaphysical feature of experience, but must be something that contributes to the overall phenomenal character of the experience-present in experience throughout." ${ }^{127}$ However, this is exactly where Suhrawardi unexpectedly turns away from all too familiar traces of Neoplatonism in philosophies of consciousness by stating: ${ }^{128}$

[117] Light is evident, and its being evident is its being light. Some incorrectly argue that our vision makes evident the light of the Sun, whereas in reality its being evident is its being light. Were there no men and nothing at all possessed of senses, it would not cease to be light.

Section 117 advances a considerable distance both from the extraction of the principle of self-evidentiality from visual reference and from the transfer of this abstraction to characterize consciousness. Even though Suhrawardi uses reduction of subject-object relationships (jarrada) as an entry into the analysis of consciousness, he does not absolutize resulting subjectivity in the same manner as does, say, Vedanta-i.e., by annulling the reality of the world. The abstraction in section 117 transcends the order of the natural subject-object givenness and raises the principle of light to the level of absolute evidentiality. This distinguishes him from Husserl who, especially in his late work Experience and Judgement, limits the first level of self-evidentiality to passive (pre-predicative) pregivenness of objects but does so under the presence of phenomenological and transcendental reductions. ${ }^{129}$ In contrast, Suhrawardī turns self-evidentiality into a principle which is not limited to human knowledge, but rather, serves as a principal metaphysical property of the universe, and thereby spans both visual light and selfawareness, and both objects and selves. Notably, Suhrawardī doesn't term this principle "being", which would open into hermeneutics, but retains the descriptive attitude in which "being evident is being light". Thereby, the knower-knowing-known relationships in PI appear against the background of the principle of light/selfevidentiality which, being a unitive, transcendental principle, accounts for knowledge aprioristically.

If we juxtapose Suhrawardī's transcendental principle of evidentiality with phenomenology's principle of phenomenalization, i.e., if we interpret $P I$ as a philosophy of consciousness, we will see that embodiment, flesh, or phenomenological materiality do not account for evidentiality, but the other way around: the phenomenalized embodiment with its perceptual consequences would be contingent on this universal principle of evidentiality. This principle is both "light in itself" and "light of itself but in the other,"130 i.e., presupposes intersubjectivity. Since Suhrawardi’s argument initially starts from the givenness of visual light, and not from the givenness of the subject, ${ }^{131}$ the fact that we see others creates a reference to other self-aware selves. Suhrawardi ends up outlining three modes of the phenomenalization of self-evidentiality of light: in the self, in the other, and with regard to the

126 Frankfurt, Importance, 161-162; also cf. Henry, “Ontological Destruction.”

127 Howell and Thompson, "Phenomenally Mine,” 106.

128 PI 2, 81.

129 Husserl, Experience, 19-21.

130 PI 2, 221, 83.

131 An anonymous reviewer of an earlier version of this paper insisted that "self-awareness is the paradigmatic type of zuhur" (whatever is meant by "paradigmatic type") and accordingly that this is what Suhrawardi means at the begining of PI. Such doctrinal presuppositions prevent one from following the text-a flaw in thinking commonly known as putting the cart before the horse. 
dusky substances (i.e., visual). ${ }^{132}$ His use of the term "light" is not exactly a metaphor or simile, as it is commonly understood, but rather, a signification of a universal metaphysical principle.

This explication of light brings all three aspects of its phenomenality to final unity: Suhrawardi argues that self-evidentiality is a principle determining life at large. Step 7 of his transcendental argument is a claim that the self-aware and self-luminous character of nūr mahd mujarrad means that nūr is alive. Accordingly, a provisional distinction between the visual light ( and the sensorium) and the essence of subjectivity resolves into the "third" principle between these two-that is, self-evidential life: ${ }^{133}$

[121] Life is a thing's being evident to itself, and a living thing is percipient and active.... Thus, pure light is alive, and every living thing is pure light. If a dusky thing perceived its own essence, it would be light in itself and not a dusky substance. By contrast, the dusky substances are lifeless, and are simply "concrete things with particular properties."

Suhrawardī's ideas regarding self-evidentiality and life resonate neither with Husserl's concept of lifeworld no Merleau-Ponty's ideas of intertwining of visibility and flesh. With ideas of self-evidentiality in manifestation and of the unity of the essence and existence of light, Suhrawardi is closer to Henry, especially in Henry's criticism of the cogito-less nature of the reversibility thesis as it stands in Merleau-Ponty. However, while Henry grounds phenomenalization in the invisible (cf. dusky substances), Suhrawardi stresses the primary and principal nature of self-evidentiality--and their views on subjectivity are yet to be compared. Since for Suhrawardi the self is the locus of unveiling the principle of self-evidentiality within itself (cf. "light in itself" in 109 as cited above), knowledge is grounded in first-person consciousness. ${ }^{134}$ That noted, the teleology of Suhrawardi's argument goes in a direction if not opposite then orthogonal to Neoplatonist thinking, in which "the world of Form, the realm of the spirit, is the primary object of experience with reference to which we may understand the visible world." 135 Rather, world and self-appear in a complicated dialectics: as knower/known, as knowers within the world, and so on, each time under a different kind of revealing reduction-also in need of further analysis with regard to different kinds of reduction which reveal these relationships in PI.

It follows from his original emphasis on the self-evidentiality of light that Suhrawardi does not fit easily within doctrinal philosophical idea-camps. ${ }^{136}$ It is not accidental that his analysis of light shows so many parallels with the physics of light: by following a filum Ariadnis of self-evidentiality, he uncovers the phenomenological initially, and the metaphysical in the second round of analysis, the horizon of the subject-object unity in the Light of Lights. In sections 115 and 116 and later, this principle is found to be active in the individual cognizing self, becoming a locus of knowledge. Suhrawardì does not distinguish between empirical and intellectual levels of knowledge directed at the self as does, say, Fichte. The principle of self-evidentiality allows for self-knowledge to be nonrepresentational; the absolute subject doesn't represent anything, and the absolute object doesn't have an independence of the thing-in-itself-in fact, they do not exist in such modes. ${ }^{137}$ They appear as a single, unified gestalt. The knower is the knowing and the known.

With regard to knowledge of the world, Suhrawardī's nonrepresentational understanding of knowledge redefines it so that the distinction between empirical and transcendental consciousness loses its meaning. Of course, what we perceive is constituted by the ego (cf. Merleau-Ponty as quoted above: "the perceived thing is paradoxical; it exists only in so far as someone can perceive it”), but the act of knowledge is itself ontologically conditioned on self-evidentiality. If one suspends the hyletic reference, and the consequent subject-object opposition, then the idea that awareness and light can be ontologically the same entity is not so absurd as it may appear at first blush. The symmetry between Suhrawardī's analysis and "objectivistic" findings extends into the scientific metaphysics of biological life. Life-that is, organic molecules-emerges out of inorganic molecules that provide the building blocks for organic molecules. ${ }^{138}$ Such a process (e.g., the emergence of amino acids in interstellar space) depends on light. ${ }^{139}$ Under certain conditions, matter inexorably acquires the key physical

132 Cf. Forrestier, "The Phenomenon”.

133 PI 83.

134 For the analysis of the primacy of self-knowledge, see Yazdì, Principles, 81-83. Cf. Marbach, "No Heterophenomenology." Notice the difference from analytic philosophy, in which "luminosity" is a characteristic of a mental states "iff, roughly, one cannot be in that state without being in a position to know that one is in it" (Hemp, The KK), i.e., is not an innate property of the pure subjectivity of awareness, of awareness itself, or of self-awareness.

135 Schroeder, Form, 3-4, 5; cf. Rappe, Reading Neoplatonism.

136 Cf. the refutation of categorizing phenomenology as idealism, etc., in Zahavi, Husserl's Legacy. Suhrawardī’s position fits well with Husserl's own distaste for doctrinal philosophizing.

137 I use the analysis of Fichte in Luft, "Phenomenology," 121.

138 Gupta, "Emergence”; Tamulis and Grigalavicius, "Emergence.”

139 Meinert et al., "Photochirogenesis." 
attributes associated with life. Jeremy England, a scientist from the Massachusetts Institute of Technology who is credited with the physical proof of necessity of life to the universe, states: ${ }^{140}$

You start with a random clump of atoms, and if you shine light on it for long enough, it should not be so surprising that you get a plant.... I am certainly not saying that Darwinian ideas are wrong. On the contrary, I am just saying that from the perspective of the physics, you might call Darwinian evolution a special case of a more general phenomenon.

Further evolution of such an "illumined" mixture of newly developed amino acids depends on the formation of light-sensitive proteins, which are the same proteins as those responsible for vision. ${ }^{141}$ As physicists say, "Without light, there would be no sight." ${ }^{142}$ And it may very well be that vision and visual consciousness, if it is even possible to consider the two separately, evolves first, before all other kinds of consciousness. ${ }^{143}$ In line with Suhrawardī, this initial restructuring of matter under the impact of light, the emergence of the sense of vision, and the development of consciousness would be expressions of the same principle of the evidential, self-explicating "telos" of the universe. Whenever we understand something, this is a self-actualization of the same principle. As Peter Costello remarked, even if we are not phenomenologists, we are engaged in explication. According to Suhrawardī, such explication is as much ours as it is the universe's. Seeing light means that the universe and ourselves are closely bonded by the principle of self-evidential knowledge.

\section{References}

Allen, Jeffner. "What Is Husserl's First Philosophy?” Philosophy and Phenomenological Research 42:4 (1982), 610-620. Antonov, Vladimir, and Galina Vaver. Complexnaya Systema Psychophysicheskoi Samoregulatsii. [A Handbook of Complex System of Psychophysical Self-Regulation.] Leningrad: Cosmos, 1989.

Aristotle. De Anima. Volume 1. Edited by Immanuel Bekker. Berlin: Akademie Verlag, 1831.

Berg, Jeremy M. "Photoreceptor Molecules in the Eye Detect Visible Light." Current Neurology and Neuroscience Reports, January 1, 1970. Retrieved from https://www.ncbi.nlm.nih.gov/books/NBK22541/. Accessed November 12, 2018.

Bergo, Bettina. "Emmanuel Levinas." In The Stanford Encyclopedia of Philosophy (Fall 2017 Edition), edited by Edward N. Zalta. Retrieved from https://plato.stanford.edu/archives/fall2017.entries/levinas/. Accessed May 10, 2019.

Bigg, Charles. Neoplatonism. London: Society for Promoting Christian Knowledge, 1895.

Carr, David. Phenomenology and the Problem of History. Evanston: Northwestern University Press, 1974.

Carr, David. “Translator's Introduction.” In Edmund Husserl, The Crisis of European Philosophy, translated by David Carr, xvxliii. Evanston: Northwestern University Press, 1970.

Chapell, Timothy. "Varieties of Knowledge in Plato and Aristotle.” Topoi 28 (2013), 175-190. Retreived from doi: 10.1007/s11245-012-9125-z.

Cherubin, R. "Inquiry and What Is: Eleatics and Monisms." Epoche: A Journal for the History of Philosophy 8:1 (2003), 1-26. Retrieved from https://search.proquest.com/docview/43071580?accountid=14505. Accessed May 4, 2019.

Costello, Peter. "From Other People to the World to Other People Again; or, To Paraphrase the Hobbit, There and Back Again." Lecture given to the Society for the Phenomenology of Religious Experience, Berkeley, CA, September 28, 2018.

Crystal, Ian. "The Scope of Thought in Parmenides." Classical Quarterly 52:1 (2002), 207-219. Retrieved from https://search.proquest.com/docview/201669550?accountid=14505. Accessed May 4, 2019.

Dastur, Françoise. “World, Flesh, Vision.” In Chiasms, edited by Fred Evans and Leonard Lalor, 23-49. Albany: SUNY Press, 2000.

Embree, Lester E. Reflective Analysis. Bucharest: Zeta Books, 2006.

Feinberg, Todd E., and Jon Mallatt. “The Nature of Primary Consciousness: A New Synthesis.” Consciousness and Cognition 43 (2016), 113-27. Retreived from doi: 10.1016/j.concog.2016.05.009.

Forestier, Florian. "The Phenomenon and the Transcendental: Jean-Luc Marion, Marc Richir, and the Issue of Phenomenalization.” Continental Philosophy Review 45 (2012), 381-402. Retreived from https://doi.org/10.1007/s11007-012-9227-8

Gupta, V. K. "Emergence of Photoautotrophic Minimal Protocell-Like Supramolecular Assemblies: 'Jeewanu’ Synthesised Photo-Chemically in an Irradiated Sterilised Aqueous Mixture of Some Inorganic and Organic Substances." Origins of Life and Evolution of Biospheres 44:4 (2014), 351-355. Retreived from doi: 10.1007/s11084-014-9381-6.

Gutas, Dimitri. Avicenna and the Aristotelian Tradition: Introduction to Reading Avicenna's Philosophical Works. Leiden: Brill, 2014.

140 Wolchover, "New Thermodynamics Theory."

141 Williams, "Light."

142 Physics Classroom, "Reflection."

143 Feinberg and Mallatt, "Nature.” 
Haaparanta, Leila. “Analysis as the Method of Logical Discovery: Some Remarks on Frege and Husserl.” Synthèse 77:1 (1988), 73-97.

Hartimo, M. “Husserl's Pluralistic Phenomenology of Mathematics.” Philosophia Mathematica 3:20 (2012), 86-110.

Hartmann, Klaus. “On Taking the Transcendental Turn.” The Review of Metaphysics 20:2 (1966), 223-49. Retreived from http://www.jstor.org/stable/20124228.

Heath, Peter. Allegory and Philosophy in Avicenna (Ibn-Sīnā). Philadelphia: University of Pennsylvania Press, 1992.

Hemp, David. “The KK (Knowing That One Knows) Principle”. Internet Encyclopedia of Philosophy. Retreived from https://www.iep.utm.edu/kk-princ/. Accessed June 30, 2019.

Henry, Michel. The Essence of Manifestation. Translated by Gigard Etzkorn. The Hague: Martinus Nijhoff, 1973.

Henry, Michel. Incarnation: A Philosophy of the Flesh. Translated by Karl Hefty. Evanston: Northwestern University Press, 2015. [Originally published as Incarnation: Une philosophie de la chair. Paris: Seuil, 2000.]

Henry, Michel. Material Phenomenology. New York: Fordham University Press, 2008.

Henry, Michel. "Ontological Destruction of the Kantian Critique of the Paralogism of Rational Psychology." Analecta Hermeneutica 8 (2016), 17-53. Retreived from http://journals.library.mun.ca/ojs/index.php/analecta/article/view/1708. Accessed April 26, 2019.

Henry, Michel. "Phénoménologie non-intentionnelle: Une tâche de la phénoménologie à venir." In L'intentionnalité en question: Entre phénoménologie et sciences cognitives, edited by Dominique Janicaud, 383-97. Paris: Vrin, 1995.

Henry, Michel. Philosophy and Phenomenology of the Body. Translated by Girard Etzkorn. The Hague: Martinus Nijhoff, 1975. [Originally published as Philosophie et phénoménologie du corps. Paris: PUF, (1965) 1987].

Hoeppe, Götz. Why the Sky is Blue: Discovering the Color of Life. New Jersey: Princeton University Press, 2007.

Howell, Robert J., and Brad Thompson. "Phenomenally Mine: In Search of the Subjective Character of Consciousness." Review of Philosophy and Psychology 8 (2017), 103-127.

Husserl, Edmund. The Crisis of. the European Sciences and Transcendental Phenomenology. Evanston: Northwestern University Press, 1970.

Husserl, Edmund. Experience and Judgement: Investigations in Genealogy of Logic. Translated by James Churchill and Karl Ameriks. London: Routledge and Kegan Paul, 1973.

Husserl, Edmund. Cartesian Meditations. Translated by Dorian Cairns. Dordrecht: Kluwer, 1993.

Husserl, Edmund. Ideas Pertaining to a Pure Phenomenology and to a Phenomenological Philosophy, First Book: General Introduction to Pure Phenomenology. Translated by F. Kersten. Dordrecht: Kluwer, 1998.

Husserl, Edmund. Logical Investigations/Logische Untersuchungen. Volume 2. London: Routledge, 2001.

Husserl, Edmund. The New Yearbook for Phenomenology and Phenomenological Philosophy. Volume 2. Edited by Burt Hopkins and Steven Crowell. New York: Routledge, 2002.

Husserl, Edmund. Zur phänomenologischen Reduktion: Texte aus dem Nachlass (1929-1935). Edited by Sebastian Luft. Husserliana 34. Dordrecht: Springer, 2002.

Huth, Gerald C. "A New Physics-Based Model for Light Interaction with the Retina of the Human Eye and the Vision Process." Rethinking the Process of Vision RSS, n.d. Retreived from http://www.ghuth.com/a-new-physics-based-model-for-lightinteraction-with-the-retina-of-the-human-eye-and-the-vision-process/. Accessed November 15, 2018.

Huth, Gerald C. "The Physics of the Vision Process." Rethinking the Process of Vision RSS, n.d. Retreived from http://www.ghuth.com/2011/01/10/the-process-of-vision/. Accessed November 12, 2018.

Kalderon, Mark E. Form without Matter: Empedocles and Aristotle on Color Perception. Oxford: Oxford University Press, 2015.

Kampakoglou, Alexandros, and Anna A. Novokhatko, eds. Gaze, Vision, and Visuality in Ancient Greek Literature. Berlin: Walter de Gruyter, 2018.

Kant, Immanuel. Critique of Pure Reason. Translated by Norman Kemp Smith. New York: St. Martin's Press, 1929.

Kee, Hayden. "Phenomenological Reduction in Merleau-Ponty's The Structure of Behavior: An Alternative Approach to the Naturalization of Phenomenology." European Journal of Philosophy, 2019. Retrieved from doi:10.1111/ejop.12452.

Kelsey, Sean. "Color, Transparency, and Light in Aristotle."Phronesis 63:2 (2018), 209-210.

Koenderink, Jan. “Kalderon, M. E., Form without Matter: Empedocles and Aristotle on Color Perception.” Perception 44:12 (2015), 1433-1436. Retrieved from doi:10.1177/0301006615610211. Accessed April 14, 2019.

Lawn-i zuhūr. [The Tablet of Manifestations or of the Divine Theophany.] Translated by Stephen Lambden, 2006. Retreived from https://hurqalya.ucmerced.edu/node/449. Accessed June 29, 2019.

LaRocca, D., ed. The Bloomsbury Anthology of Transcendental Thought. New York: Bloomsbury, 2017.

Long, Christopher P. "On Touch and Life in the De Anima." In Phenomenology and the Metaphysics of Sight, edited by Antonio Cimino and Pavlos Kontos, 71-94. Leiden: Brill, 2015.

Louchakova-Schwartz, 0. “A Phenomenological Approach to Illuminationist Philosophy: Suhrawardī’s nūr mujarrad and Husserl's Reduction." Philosophy East and West 64:2 (2015), 1052-1081.

Luft, Sebastian. "Husserl's Notion of the Natural Attitude and the Shift to Transcendental Phenomenology." Analecta Husserliana 80 (2002), 114-119.

Luft, Sebastian. "Husserl's Theory of the Phenomenological Reduction: Between Lifeworld and Cartesianism." Research in Phenomenology 34 (2004), 198-234. 
Luft, Sebastian. “Phenomenology as First Philosophy: A Prehistory.” In Philosophy, Phenomenology, Sciences, edited by Carlo lerna, Hanne Jacobs, and Filip Mattens, 107-133. Dordrecht: Springer, 2010.

Marbach, Eduard. "No Heterophenomenology without Autophenomenology: Variations on a Theme of Mine." Phenomenology and the Cognitive Sciences 6 (2007), 75-87. Retreived from doi: 10.1007/s11097-006-9027-x.

Marcotte, Roxanne. "Suhrawardi." In The Stanford Encyclopedia of Philosophy (Summer 2019 Edition), edited by Edward N. Zalta. Retreived from <https://plato.stanford.edu/archives/sum2019/entries/suhrawardi/>. Accessed April 29, 2019.

Max-Planck-Institut für biologische Kybernetik. “Quick Links.” Virtual Reality Equipment, n.d. Retreived from http://www.kyb.tuebingen.mpg.de/research/dep/lo/visual-perception.html. Accessed November 12, 2018.

McGinnis, Jon. “New Light on Avicenna: Optics and Its Role in Avicennian Theories of Vision, Cognition, and Emanation.” In Philosophical Psychology in Arabic Thought and the Latin Aristotelianism of the 13th Century, edited by Luis Xavier LópezFarjeat and Jörg Alejandro Tellkamp, 41-57. Paris: Vrin, 2012.

Meinert, Cornelia, et al. [Meinert, Cornelia, Pierre de Marcellus, Louis Le Sergeant d'Hendecourt, Laurent Nahon, Nykola C. Jones, Søren V. Hoffmann, Jan Hendrik Bredehöft, and Uwe J. Meierhenrich.] "Photochirogenesis: Photochemical Models on the Absolute Asymmetric Formation of Amino Acids in Interstellar Space.” Physics of Life Reviews 8:3 (2011), 307-330. Retreived from doi: https://doi.org/10.1016/j.plrev.2011.08.005.

Merleau-Ponty, Maurice. The Primacy of Perception. Evanston: Northwestern University Press, 1964.

Merleau-Ponty, Maurice. Phenomenology of Perception. New York: Routledge, 2012.

Miller, P. L. Becoming God: Pure Reason in Early Greek Philosophy. London: Continuum, 2012. Retrieved from https://search.proquest.com/docview/926956062?accountid=14505. Accessed May 4, 2019.

Montag, Ethan D. “Vision and Psychophysics.” Rochester Institute of Technology, n.d. Retreived from https://www.cis.rit.edu/people/faculty/montag/vandplite/pages/chap_9/ch9p1.html. Accessed October 12, 2018.

Moran, Dermot. Husserl's Crisis of the European Sciences and Transcendental Phenomenology: An Introduction. Cambridge: Cambridge University Press, 2012.

More, Tom. "Why Visual Content Is Crucial to Customer Engagement." Salesforce Blog, 2014. Retreived from https://www.salesforce.com/blog/2014/09/visual-content-customer-engagement-gp.html. Accessed October12, 2018.

Moskowitz, Clara. “Hidden in Einstein’s Math: Faster-than-Light Travel?” LiveScience. Retrieved from https://www.livescience.com/23789-einstein-relativity-faster-than-light-travel.html. Accessed May 2, 2019.

Nasr, Seyyed Hossein. “General Introduction”. In An Anthology of Philosophy in Persia. Volume 2. Edited by Seyyed Hossein Nasr and Mehdi Aminrazavi, 1-15. London: I.B. Tauris.

Noë, Alva, and J. Kevin O’Regan. "On the Brain-Basis of Visual Consciousness: The Sensory-Motor Account.” In Vision and Mind, edited by Alva Noë and Evan Thompson, 567-598. Cambridge, Mass.: MIT Press, 2002.

The Physics Classroom. "Reflection and the Ray Model of Light: The Role of Light to Sight.” Physics Tutorial, n.d. Retreived from https://www.physicsclassroom.com/class/refln/Lesson-1/The-Role-of-Light-to-Sight. Accessed October 12, 2018.

Pietersma, Henry. “Husserl’s Concept of Existence.” Synthèse 66:2 (1986), 311-328.

Prier, Raymond A. Thauma Idesthai. Gainesville: Florida State University Press, 1989.

Rappe, Sara. Reading Neoplatonism: Non-discursive Thinking in the Texts of Plotinus, Proclus and Damascius. Cambridge: Cambridge University Press, 2000.

Rudolph, Kelli. "Sight and the Presocratics: Approaches to Visual Perception in Early Greek Philosophy." In Sight and the Ancient Senses, edited by Michael Squire, 36-53. Routledge, 2015.

Russell, Bertrand. The Problems of Philosophy. New Delhi: Prabhat Prakashan, 2016.

Schroeder, Frederick M. Form and Transformation: A Study in the Philosophy of Plotinus. Montreal: McGill University Press, 1992.

Seifert, Josef. Discours des méthodes. Paris: Vrin, 2009.

Serban, Claudia. "Beneath Time and Reflection: The Shadow of Husserl in Michel Henry's Non-intentional Phenomenology." Analecta Hermeneutica 8 (2016): 234-244.

Seyler, Frédéric. “Michel Henry.” In The Stanford Encyclopedia of Philosophy (Winter 2016 Edition), edited by Edward N. Zalta. Retreived from <https://plato.stanford.edu/archives/win2016/entries/michel-henry/>. Accessed October 15, 2018.

Snell, Bruno. The Discovery of the Mind. Translated by T. G. Rosenmeyer. Oxford: Blackwell, 1953. [Originally published as Die Entdeckung des Geistes: Studien zur Entstehung des europäischen Denkens bei den Griechen. Hamburg: Claaszen \& Goverts, 1946].

Sparrow, Tom. The End of Phenomenology. Edinburgh: Edinburgh University Press, 2014.

Steinbock, Anthony. "Generativity and the Scope of Generative Phenomenology." In The New Husserl: A Critical Reader, edited by Donn Welton, 289-325. Bloomington: Indiana University Press, 2003.

Stern, Robert. "Transcendental Arguments." In The Stanford Encyclopedia of Philosophy (Summer 2017 Edition), edited by Edward N. Zalta. Retreived from <https://plato.stanford.edu/archives/sum2017/entries/transcendental-arguments/>. Accessed October 15, 2018.

Suhrawardī [Sohravardi], Yaḥyá ibn Ḥabash. The Book of Radiance. Translated by Hossein Ziai. Costa Meza, California: Mazda Publishers, 1980.

Suhrawardī [Sohravardi], Yaḥyá ibn Ḥabash. The Philosophy of Illumination = Hikmat al-Ishrāq: A New Critical Edition of the Text of Hikmat al-Ishrāq. Translated by John Walbridge and Hossein Ziai. Provo: Brigham Young University Press, 1999. 
Taguchi, Shigeru. Das Problem des "Ur-Ich" bei Edmund Husserl: Die Frage nach der selbstverständlichen "Nähe" des Selbst/The Problem of the "Ur-Ich" in Edmund Husserl: The Question of the Self-Understanding "Proximity" of the Self. Dordrecht: Springer, 2006.

Tamulis, Arvydas, and Mantas Grigalavicius. "The Emergence and Evolution of Life in a 'Fatty Acid World' Based on Quantum Mechanics.” Origin of Life and Evolution of Biospheres 41:1 (2011), 51-71. Retreived from doi: 10.1007/s11084-010-9211-4.

Tarditi, Claudio. "Seeing the Invisible: Jean-Luc Marion's Path from Husserl to Saint Paul.” In Phenomenology and the Metaphysics of Sight, edited by Antonio Cimino and Pavlos Kontos, 142-162. Leiden: Brill, 2015.

Tononi, G., and C. Koch. "Consciousness: Here, There and Everywhere?" Philosophical Transactions of the Royal Society B: Biological Sciences 370:1668 (2015). Retreived from http://doi.org/10.1098/rstb.2014.0167. Accessed October 3, 2018.

Üçer, İbrahim Halil. "From Identity to Representation: Ibn Sına on the Identity of Knower and Known in the Human Rational Soul," Nazariyat Journal for the History of Islamic Philosophy and Sciences 4:2 (2018), 1-55.

Veríssimo, Danilo Saretta. “Husserl's Theory of Perceptive Donation according to Profiles." Psicologia USP 27:3 (2016), 521-530. Retreived from https://dx.doi.org/10.1590/0103-656420150043.

Walbridge, John. The Leaven of the Ancients. Albany: SUNY Press, 1999.

Walbridge, John, and Hossein Ziai. “Translators' Introduction.” In Suhrawardī, The Philosophy of Illumination [q.v.], xv-xvii. Provo: Brigham Young University Press, 1999.

Wheeler, Michael. “Martin Heidegger.” In The Stanford Encyclopedia of Philosophy (Winter 2018 Edition), edited by Edward N. Zalta. Retreived from https://plato.stanford.edu/archives/win2018/entries/heidegger/. Accessed May 15, 2019.

Whittaker, J. God, Time, Being: Two Studies in the Transcendental Tradition in Greek Philosophy. Oslo: Universitetsforlaget, 1971. Retrieved from https://search.proquest.com/docview/42522953?accountid=14505. Accessed May 4, 2019.

Williams, David L. "Light and the Evolution of Vision." Eye 30:2 (2016), 173-178.

Wolchover, Natalie. "A New Thermodynamics Theory of the Origin of Life.” Quanta Magazine, n.d. Retreived from https://www.quantamagazine.org/a-new-thermodynamics-theory-of-the-origin-of-life-20140122/. Accessed November 13, 2018.

Wynne, Parry. "Why the Speed of Light Matters.” LiveScience, September 26, 2011. Retreived from https://www.livescience.com/16248-speed-light-special-relativity-neutrinos.html. Accessed May 1, 2019.

Yazdī, Mahdī Ḥā'irī. The Principles of Epistemology in Islamic Philosophy: Knowledge by Presence. Albany: SUNY Press, 1992.

Zahavi, Dan. Husserl's Legacy: Phenomenology, Metaphysics, and Transcendental Philosophy. New York: Oxford University Press, 2017.

Zahavi, Dan. "Consciousness, Self-Consciousness, Selfhood: A Reply to Some Critics." The Review of Philosophy and Psychology 9:3 (2018), 703-718.

Ziai, Hossein. “Illuminationism.” Encyclopedia Iranica, vol. 12, fasc. 6 ([2004] 2012), 670-672. 